\title{
IDENTIFIKASI FAKTOR PENENTU MOBILITAS DI KECAMATAN SUKARAJA
}

\author{
Alnur Fitria Ningsih', Hutapia ${ }^{2)}$ \\ ${ }^{1}$ Jurusan Ekonomi Pembangunan Fakultas Ekonomi dan Bisnis Universitas Bengkulu \\ Email: alnur@mail.com \\ ${ }^{2}$ Jurusan Ekonomi Pembangunan Fakultas Ekonomi dan Bisnis Universitas Bengkulu
}

Email: hutapia@unib.ac.id

\begin{abstract}
This study aimed to analyze the charasteristics factors which are able to influence the workers decision to commit commuting migration in Sukaraja subdistrict of Seluma regency. This research is descriptive research that will analyze the effect charasteristics of wage, age, level of education, marriage, sex and land to the workers decision to commit commuting migration in Sukaraja subdistrict of Seluma regency. The research was conducted by an experimental apptoach using primary data. Samples were taken as 100 respondents in proportional random sampling with random sampling method. Analysis of the data used descriptive analysis. The results showed difference in charasteristics of wage, age, level of education, marriage, sex and land to influence the workers decision to commit commuting migration in Sukaraja subdistrict of Seluma regency
\end{abstract}

Keywords: commuting migration, wage, age, level of education, marriage, sex and land

\section{PENDAHULUAN}

Mobilitas penduduk dari desa ke kota sangat mewarnai di beberapa negara berkembang, termasuk di berbagai daerah di Indonesia. Mantra dalam Indriani (2010) menyatakan bahwa Mobilitas penduduk merupakan gerak penduduk yang melintasi batas wilayah dalam periode waktu tertentu, yaitu mobilitas penduduk permanen ditandai dengan adanya niatan untuk menetap di daerah tujuan dan mobilitas penduduk nonpermanen ditandai oleh tidak adanya niatan untuk menetap di daerah tujuan. Mobilitas penduduk nonpermanen dibagi menjadi dua yaitu mobilitas ulang alik atau harian dan mobilitas penduduk yang mondok/ menginap atau mobilitas penduduk sirkuler di daerah tujuan. Ulang alik adalah gerak penduduk dari daerah asal menuju ke daerah tujuan dalam batas waktu enam jam atau lebih meninggalkan daerah asal dan kembali pada hari yang sama. Mondok/menginap adalah gerak penduduk dari daerah asal menuju daerah tujuan dalam batas waktu lebih dari satu hari, tetapi kurang dari enam bulan.

Lee (1966) dan Todaro (1979) berpendapat bahwa motivasi seseorang untuk pindah adalah motif ekonomi. Motif tersebut berkembang karena adanya ketimpangan ekonomi antar daerah. Todaro menyebut motif utama tersebut sebagai pertimbangan ekonomi rasional, dimana seseorang melakukan mobilitas ke kota adalah adanya harapan untuk memperoleh pekerjaan dan memperoleh pendapatan yang lebih tinggi daripada yang diperoleh di pedesaan. Sejalan dengan Mantra, Robert dan Smith yang dikutip oleh Hossain dalam Abidin (2013) menyatakan bahwa tidak meratanya pekerjaan dan penghasilan pertanian di pedesaan menjadi motivasi melakukan mobilitas desa ke kota. Dengan demikian, perpindahan desa ke kota sekaligus mencerminkan adanya ketidak seimbangan antara kedua daerah tersebut.

Perpindahan penduduk dari daerah pedesaan ke daerah perkotaan menjadi salah satu bagian dari proses pembangunan. Aktivitas perpindahan penduduk dari desa ke kota hanya merupakan salah satu penyebab proses urbanisasi, di samping penyebab-penyebab lain seperti pertumbuhan alamiah penduduk perkotaan, perluasan wilayah, maupun perubahan status wilayah dari daerah pedesaan menjadi daerah perkotaan. Proses urbanisasi di Indonesia diperkirakan akan lebih banyak disebabkan migrasi desa-kota, yang didasarkan pada makin rendahnya pertumbuhan alamiah penduduk di daerah perkotaan, relatif lambannya perubahan status dari daerah pedesaan menjadi 
daerah perkotaan, serta relatif kuatnya kebijaksanaan ekonomi dan pembangunan yang "urban bias", sehingga memperbesar daya tarik daerah perkotaan bagi penduduk yang tinggal di daerah pedesaan (Prijono, 2000).

Faktor pesatnya pertumbuhan ekonomi di kota besar serta pesatnya pertumbuhan penduduk dengan persebaran yang tidak merata, membuat sebagian besar penduduk terdorong melakukan mobilitas ke kota yang lebih besar tersebut. Di kota tujuan tersebut terdapat kesempatan kerja yang lebih besar dengan jenis pekerjaan yang beragam, adanya berbagai fasilitas, dan dari segi ekonomi mereka yang melakukan mobilitas tersebut mengharap suatu kehidupan layak dengan pendapatan yang lebih besar dari pada di daerah asal. Khodijah (2008) menemukan bahwa terjadinya mobilitas desa ke kota biasanya didorong oleh tertinggalnya pertumbuhan desa dibandingkan pertumbuhan kota.

Menurut Yeremias (1994) dan Susilowati (1998) menyatakan bahwa keputusan bermigrasi dipengaruhi oleh latar belakang individu yang meliputi faktor umur, status perkawinan, lama tinggal di desa, status pekerjaan di desa, kepemilikan tanah di desa, jenis pekerjaan di kota, pendapatan dan tingkat pendi- dikan; faktor latar belakang struktural yang meliputi variabel karakteristik kota tempat kerja migran dan jarak dari desa asal ke kota tempat kerja; dan faktor place utility yang meliputi variabel jenis nilai yang diharapkan, kepuasan kerja, dan kesukaan hidup di kota daripada di desa. munculnya fenomena keputusan tenaga kerja menjadi commuter.

Salah satunya adalah fenomena commuter yang terjadi di Provinsi Bengkulu. Hal ini ditunjukan dengan adanya aktivitas masyarakat desa pergi ke kota dengan niatan untuk bekerja atau mencari pekerjaan. Kota Bengkulu merupakan ibu kota provinsi Bengkulu yang menjadi kota perdagangan yang cukup maju dengan jenis pekerjaan yang lebih beragam. jika dibandingkan dengan daerah lainnya di Provinsi Bengkulu sehingga menarik banyak penduduk dari daerah sekitarnya. Selain itu menurut data Badan Pusat Statistik Provinsi Bengkulu tahun 2017 jumlah penduduk Provinsi Bengkulu yaitu sebesar 1.934.269 jiwa dimana pendu- duknya tersebar di sepuluh kabupaten/kota dengan komposisi jumlah angkatan kerja pada tahun 2017 mencapai angka 969.255 jiwa dengan tingkat partisipasi angkatan kerja (TPAK) sebesar 69.30.

Persebaran tenaga kerja di Provinsi Bengkulu menurut kabupaten/kota memiliki variasi yang cukup beragam. Secara umum ibu kota induk kabupaten lama seperti Kota Bengkulu, Kabupaten Rejang Lebong dan Bengkulu Utara memiliki jumlah angkat an kerja yang lebih tinggi dibandingkan dengan kabupaten pemekaran. Kabupaten Seluma sebagai kabupaten pemekaran memiliki jumlah angkatan kerja yang tinggi jika dibandingkan dengan Kabupaten Bengkulu Selatan sebagai ibu kota kabupaten induk lama yaitu sebesar 104.686 jiwa dan memiliki TPAK tertinggi yaitu sebesar 76.70. Selain itu Kabupaten seluma memiliki jarak yang dekat dengan Kota Bengkulu. Sehingga tenaga kerja di daerah tersebut memiliki peluang besar untuk melakukan mobilitas non permanen atau commuter.Hal ini dikarena tidak semua tenaga kerja akan terserap secara penuh di daerahnya.

Terdapat lima kecamatan yang memiliki jumlah penduduk terbanyak yang menyumbang tenaga kerja di Kabupaten Seluma yaitu Kecamatan Sukaraja dengan jumlah penduduk sebesar 33.658 jiwa, diikuti oleh Kecamatan Semidang Alas Maras dengan jumlah penduduk sebesar 23.124 jiwa , kemudian Kecamatan Air Periukan dengan 19.082 jiwa, lalu Kecamatan Semidang Alas dengan jumlah penduduk sebesar 14.448 jiwa dan yang terakhir adalah Kecamatan Ilir Talo dengan jumlah penduduk sebesar 13.328 jiwa. Di antara lima kecamatan tersebut Kecamatan Sukaraja menduduki peringkat pertama sebagai kecamatan yang memiliki jumlah penduduk yang paling tinggi di Kabupaten Seluma. Dengan jumlah terse but akan sangat memungkinkan jika angkatan kerja di Kecamatan Sukaraja melakukan migrasi komutasi dalam jumlah yang besar pula. Berdasarkan latar belakang tersebut maka penelitian ini berjudul: Karakteristik Tenaga Kerja Commuter di Kecamatan Sukaraja. 


\section{LANDASAN TEORI}

\section{Konsep dan Definisi Mobilitas Penduduk}

Menurut Mantra pada dasarnya mobilitas penduduk dapat dibagi menjadi dua bentuk, yaitu mobilitas permanen (migrasi), dan mobilitas non-permanen atau migrasi sirkuler. Migrasi adalah perpindahan penduduk dari satu wilayah ke wilayah tujuan dengan maksud menetap. Sedangkan migrasi sirkuler ialah gerak penduduk dari satu tempat ke tempat lain tanpa ada maksud untuk menetap. Migrasi sirkuler ini pun bermacam-macam jenisnya ada yang ulang-alik, periodik, musiman, dan jangka panjang. Migrasi sirkuler dapat terjadi antara desa-desa, desa-kota, kotadesa, dan kota-kota (Abidin, 2013).

\section{Teori Migrasi oleh Everett S. Lee}

Menurut Everett S. Lee dalam Adioetomo dan Samosir (2010), volume migrasi di suatu wilayah berkembang sesuai dengan tingkat keragaman daerah-daerah di wilayah tersebut. Di daerah asal dan di daerah tujuan, menurut lee, terdapat faktor-faktor yang disebut sebagai :

a. Faktor positif (+) yaitu faktor yang memberikan nilai positif atau keuntungan bila bertempat tinggal di tempat tersebut.

b. Faktor negatif (-) yaitu faktor yang memberikan nilai negatif atau merugikan bila tinggal di tempat tersebut sehingga seseor- ang merasa perlu untuk pindah ke tempat lain.

c. Faktor netral (0) yaitu yang tidak berpengaruh terhadap keinginan seseorang individu untuk tetap tinggal di tempat asal atau pindah ke tempat lain.

Selain ketiga faktor di atas menurut Everett S. Lee (Adioetomo dan Samosir , 2010) ada empat faktor lain yang menyebabkan orang mengambil keputusan untuk melakukan migrasi, yaitu:

a. Faktor-faktor yang terdapat di daerah asal.

b. Faktor-faktor yang terdapat di tempat tujuan.

c. Rintangan-rintangan antara (jarak).

d. Faktor-faktor pribadi.

Faktor-faktor yang terdapat di daerah asal misalnya, tanah yang subur, kekerabatan yang tinggi, adanya variasi pekerjaan non-tani, dan tersedianya fasilitas sosial yang lengkap akan menarik individu untuk menetap di daerah asal. Namun jika yang terjadi adalah sebaliknya maka akan mendorong individu untuk meninggalkan daerah asalnya. Faktor-faktor yang terdapat di daerah tujuan seperti tersedianya variasi lapangan pekerjaan, fasilitas sosial lengkap, harapan mendapat upah tinggi akan menjadi penarik individu dari luar daerah, dan kemacetan, kriminalitas tinggi, bencana alam bisa menjadi faktor pendorong dari daerah tujuan. Rintangan-rintangan antara adalah mengenai jarak, dimana memperhitungkan, biaya perjalanan, sulit atau tidaknya medan untuk ditempuh, dan lama waktu perjalanan yang ditempuh. Walaupun rintangan antara (jarak) ini selalu ada, tidak selalu menjadi faktor penghalang. Rintangan-rintangan tersebut mempunyai pengaruh yang berbeda-beda pada masing-masing individu. Faktor dalam pribadi inilah yang mempunyai peranan terbesar karena faktor-faktor nyata yang terdapat di tempat asal atau tempat tujuan belum merupakan faktor utama, karena pada akhirnya kembali pada respon seseorang tentang faktor tersebut, kepekaan pribadi dan kecerdasannya.

Disamping itu, Menurut Munir dalam Adioetomo dan Samosir (2010), mengatakan bahwa faktorfaktor yang mempengaruhi migrasi ada dua faktor yaitu faktor pendorong dan faktor penarik.

1. Faktor-faktor pendorong yang menyebabkan penduduk bermigrasi

a. Makin berkurangnya sumber-sumber alam.

b. Menyempitnya lapangan pekerjaan di tempat asal, karena masuknya teknologi yang menggunakan mesin-mesin. 
c. Tidak cocok lagi dengan adat budaya/kepercayaan di daerah asal.

d. Alasan pekerjaan atau perkawinan yang menyebabkan tidak bisa mengembangkan karier pribadi

e. Bencana alam baik banjir, kebakaran musim kemarau atau adanya wabah penyakit.

2. Faktor-faktor penarik yang menyebabkan penduduk melakukan migra Adanya rasa superior di tempat yang baru atau kesempatan untuk memasuki lapangan pekerjaan yang cocok.

a. Kesempatan mendapatkan pekerjaan yang lebih baik.

b. Kesempatan mendapatkan pendidikan yang lebih tinggi.

c. Keadaan lingkungan dan keadaaan hidup yang menyenangkan.

d. Tarikan dari orang yang diharapkan sebagai tempat berlindung.

e. Adanya aktivitas kota besar, tempat-tempat hiburan, pusat kebudayaan, adanya tekanan atau diskriminasi politik, agama, suku, di daerah asal.

\section{Teori Migrasi Todaro}

Menurut Mantra (2000) dalam Teori Migrasi Todaro ini bertolak dari asumsi bahwa migrasi dari desa ke kota pada dasarnya merupakan suatu fenomena ekonomi. Keputusan seorang individu untuk melakukan migrasi ke kota merupakan keputusan yang telah dirumus- kan secara rasional. Teori Todaro mendasarkan diri pada pemikiran bahwa arus migrasi itu berlangsung sebagai tanggapan terhadap adanya perbedaan pendapatan antara desa dengan kota.

Adapun Model migrasi Todaro memiliki empat pemikiran dasar sebagai berikut :

a. Model migrasi desa-kota dirangsa ng terutama sekali, oleh berbagai pertimbangan ekonomi yang rasional dan yang langsung berka- itan dengan keuntungan atau ma- nfaat dan biayabiaya relative migrasi itu sendiri (sebagian besar terwujud dalam satuan moneter, namun ada pula yang terwujud dalam bentuk-bentuk atau ukuran lain, misalnya saja kepuasan psikologis).

b. Keputusan untuk bermigrasi ter gantung pada selisih antara tingkat pendapatan yang diharap kan di kota dan tingkat pend apatan aktual di pedesaan (penda patan yang diharapkan adalah sejumlah pendapatan yang secara rasional bisa diharapkan akan tercapai di masa-masa mendatang ).

c. Kemungkinan mendapatkan peker jaan di perkotaan berkaitan langs -ung dengan tingkat lapangan pekerjaan di perkotaan, sehingga berbanding terbalik dengan tingk- at pengangguran di perkotaan.

d. Laju migrasi desa-kota bisa saja terus berlangsung meskipun telah melebihi laju pertumbuhan kesem- patan kerja. Kenyataan ini mem- liki landasan yang rasional, karena adanya perbedaan ekspektasi pendapatan yang sangat lebar, yakni para migran pergi ke kota untuk meraih tingkat upah lebih tinggi yang nyata. Dengan demik- ian, lonjakan penganguran di perkotaan merupakan akibat yang tidak terhindarkan dari adanya kesempatan ekonomi berupa kesenjangan tingkat upah antara di perdesaan danperkotaan dan ketimpangan itu banyak ditemuka-n di Negara dunia ketiga.

\section{Teori Pilihan Rasional}

Becker dalam Susilowati (2003), menyatakan bahwa dalam menentukan suatu pilihan, seorang individu akan memilih satu diantara beberapa alternatif yang dapat memberikan kegunaan (utility) yang paling maksimum bagi dirinya. Dengan kata lain, secara rasional seseorang akan menganut prinsip ekonomi dalam menentukan pilihannya yaitu akan memilih sesuatu tempat (benefit) semaksimum mungkin dengan biaya (cost) dan resiko (risk) seminimum mungkin.

Tyler dalam Susilowati (2003), menyatakan bahwa teori pilihan yang dikemukakan Becker tersebut kemudian penerapannya dikembangkan tidak hanya di bidang ekonomi tetapi juga disiplin 
ilmu sosial lainnya seperti psikologi, sosiologi dan kriminologi. Triantoro dalam Susilowati (2003), menyatakan bahwa teori pilihan yang rasional mempunyai asumsi bahwa individu merupakan pelaku ekonomi yang rasional dan bersikap netral dalam menerima resiko (neutral risk). Dengan demikian, dalam pengambilan keputusan mereka akan memperhitungkan unsur untung-ruginya dengan tetap mempertimbangkan biaya dan manfaat dari keputusan yang diambilnya.

\section{Bentuk-Bentuk Mobilitas Penduduk}

Menurut Mantra (2000) migrasi harian (nglaju) atau commuting adalah gerak penduduk dari daerah asal menuju daerah tujuan dalam batas waktu tertentu dan kembali ke daerah asal pada hari itu juga. Sementara mobilitas penduduk adalah gerak penduduk (movement), penduduk yang melintas batas wilayah menuju ke wilayah lain dalam periode waktu tertentu. Penggunaan batas wilayah dan waktu untuk indikator mobilitas penduduk horisontal ini mengikuti paradigma ilmu geografi yang mendasark -an konsepnya atas wilayah dan waktu (Space and Time Concept).

Mobilitas penduduk dapat dibedakan antara mobilitas penduduk vertikal dan mobilitas penduduk horisontal. Mobilitas penduduk vertikal atau yang sering disebut dengan perubahan status pekerjaan. Secara ringkas bentuk-bentuk mobilitas penduduk sebagai berikut:

\section{Tabel 1 Bentuk-bentuk Mobilitas Penduduk (Berdas arkan Hasil Riset Ida Bagoes Mantra Tahun 1975)}

\begin{tabular}{rlcl}
\hline No. & $\begin{array}{l}\text { Bentuk } \\
\text { Mobilitas }\end{array}$ & Batas Wilayah & Batas Waktu \\
\hline 1. & $\begin{array}{l}\text { Ulang-alik } \\
\text { (commuting) }\end{array}$ & Dukuh (dusun) & $\begin{array}{l}\text { 6 jam atau lebih dan kembali pada } \\
\text { hari yang sama }\end{array}$ \\
2. & $\begin{array}{l}\text { Menginap/ } \\
\text { Mondok di }\end{array}$ & Dukuh (dusun) & $\begin{array}{l}\text { Lebih dari satu hari tetapi kurang dari } \\
6 \text { bulan }\end{array}$ \\
& $\begin{array}{l}\text { daerah tujuan } \\
\text { 3. }\end{array}$ & & \\
& $\begin{array}{l}\text { Permanen/mene } \\
\text { tap di daerah }\end{array}$ & Dukuh (dusun) & \\
& &
\end{tabular}

Sumber: Ida Bagoes Mantra, 2000

\section{Faktor-faktor yang Mempengaruhi Keputusan Mobilitas Non Permanen}

Menurut Todaro (1998), faktor-faktor yang mempengaruhi seseorang untuk melakukan migrasi sirkuler atau mobilitas non permanen sangat beragam- dan rumit. Hal ini disebabkan oleh selain faktor ekonomi yang berperan dalam pembuatan keputusan untuk melakukan migrasi, keputusan tersebut juga dipengar-uhi dengan banyak faktor lain yakni:

a. Faktor-faktor sosial, termasuk keinginan para migran itu sendiri untuk melepaskan diri dari kendala -kendala tradisional yang sebelu- mnya mengungkung mereka.

b. Faktor-faktor fisik, termasuk peng aruh iklim dan bencana alam seperti banjir dan kekeringan.

c. Faktor-faktor demografi, termasuk penurunan tingkat kematian yang kemudian mempercepat laju pertumbuhan penduduk pedesaan. 
d. Faktor-faktor kultural, termasuk pembinaan kelestarian hubungan "keluarga besar" sesampainya di perkotaan dan daya tarik "lampu kota yang terang benderang".

e. Faktor-faktor komunikasi. Termas- uk kualitas sarana transportasi, sist- em pendidikan, dan dampak modernisasi yang ditimbulkan dari perko taan.

\section{Pengaruh Tingkat Pendapatan}

Asumsi yang dijelaskan Todaro di atas dapat dihipotesakan bahwa dengan melakukan mobilitas sirkuler, maka pendapatan rumah tangga akan lebih baik.Keputusan untuk bermigrasi tergantung pada selisih antara tingkat pendapatan yang diharapkan di kota dan tingkat pendapatan aktual di pedesaan (pendapatan yang diharapkan adalah sejumlah pendapatan yang secara rasional bisa diharapkan akan tercapai di masa-masa mendatang Todaro dalam Mantra (2000) dan Everett S. Lee dalam Adioetomo dan Samosir (2010) juga menyatakan bahwa Upah yang tinggi dan kesempatan kerja yang menarik di daerah tujuan migran merupakan faktor penarik untuk datang ke sana dan secara rasional seseorang akan menganut prinsip ekonomi dalam menentukan pilihannya yaitu akan memilih sesuatu tempat (benefit) semaksimum mungkin dengan biaya (cost) dan resiko (risk) seminimum mungkin Becker dalam (Susilowati, 2003).

\section{Pengaruh Umur}

Zhao (1999) mengemukakan hipotesis semakin tua umur, semakin kecil kemungkinan individu untuk melakukan mobilitas sirkuler karena biaya psikologis untuk melakukan penyesuaian menghadapi lingkungan kerja dan tempat tinggal yang baru semakin besar. Menurut Ravenstein dalam Mantra (2000) bahwa penduduk yang masih muda lebih banyak melakukan migrasi, karena mempunyai fisik yang masih kuat dan produktifitas dalam bekerja masih sangat baik. Semakin bertambahnya umur tenaga kerja maka akan semakin kecil probabilitas tenaga kerja untuk melakukan commuter. Hal tersebut senada dengan hasil penelitian yang dilakukan oleh Purnomo (2004) yang menunjukkan umur memiliki pengaruh erhadap minat seseorang melakukan migrasi.

\section{Pengaruh Tingkat Pendidikan}

Menurut Todaro (1999), disimp- ulkan bahwa ada korelasi yang positif terhadap kesempatan memperoleh pendidikan dan migrasi. Orang yang berpendidikan lebih tinggi cenderung lebih banyak melakukan migrasi daripada yang pendidikannya lebih rendah. Menurut pendekatan teori human capital ( Payaman, 2001 ) dalam Hasyasya dan setiawan (2012), pendidikan merupakan aspek yang sangat penting dalam pengembangan sumber daya manusia. Dengan pendidikan yang tinggimengakibatkan produktifitas kerja yang lebih tinggi pula dan memungkinkan mendapatkan penghasilan yang lebih tinggi pula. Pendidikan yang tinggi membuat seseorang dapat lebih leluasa dalam memilih pekerjaan dan penghasilan yang diharapkan. Semakin tinggi tingkat pendidikan seorang pekerja, maka keinginan untuk melakukan commuter semakin besar.

\section{Pengaruh Status Pernikahan}

Keputusan seseorang untuk bermigrasi tergantung dari status perkawinan yang dimilikinya. Apabila sudah berstatus menikah, maka harus ada kesepakatan dari suami/istri apakah diizinkan untuk migrasi atau tidak. Apabila status seseorang belum menikah/lajang, maka ada kemungkinan untuk bermigrasi ( Hasyasya dan setiawan, 2012).

\section{Pengaruh Jenis Kelamin}

Teori Gravitasi Revenstein dalam Mantra, (2000) yang memiliki tujuh teori, ada salah satu teorinya yang menjelaskan bahwa wanita melakukan migrasi pada jarak yang dekat dibandingkan pria. Artinya, laki-laki lebih dominan melakukan migrasi dibandingkan wanita, walaupun tidak sedikit pula wanita yang melakukan migrasi, akan tetapi dalam jarak yang tidak terlalu jauh. 


\section{Pengaruh Status Kepemilikan Lahan}

Kepadatan penduduk Indonesia, menurut Saefullah (1995) pada tahun 1990 sudah mencapai 93 orang setiap kilometer persegi dan diperkirakan pada tahun 2020 naik menjadi satu setengah kali lipat. Pada akhirnya untuk memenuhi kebutuhan fasilitas sosial, terutama perumahan dan lokasi industri akhirnya lahan pertanian produktif beralih fungsi menjadi lahan non-pertanian sehingga lahan menjadi sempit yang pada gilirannya akan menciutkan kesempatan kerja dan mengurangi pendapatan petani.

\section{METODE PENELITIAN}

Jenis penelitian ini adalah penelitian yang bersifat deskriptif. Tempat penelitian ini dilaksanakan di Kecamatan Sukaraja Kabupaten Seluma dan penentuan responden penelitian menggunakan Random Sampling. Teknik pengumpulan data dalam penelitian ini menggunakan wawancara berdasarkan kuesioner dan dokumentasi. Metode yang digunakan dalam menentukan sampel adalah teknik dimana dalam penentuan besar jumlah sampel yang akan diambil akan digunakan rumus Slovin sebagai berikut (Bambang, 2005) :

$$
=1+{ }^{n} \frac{N}{1+N e^{2}}
$$

Keterangan :

$\mathrm{N}=$ Jumlah Populasi

$\mathrm{n}=$ Jumlah Sampel

$\mathrm{e}=$ Nilai kritis yang diinginkan (persen kelonggaran karena penarikan sampel ditetapkan $10 \%)$

Dari hasil perhitungan tersebut sampel yang dihasilkan adalah 99,74, maka dibulatkan menjadi 100 responden. Analisis data yang digunakan yaitu deskripsi data yang merupakan upaya menampilkan data agar dapat dipaparkan secara baik dan diinterpretasikan secara mudah. Deskripsi meliputi penyusunan data dalam bentuk yang mudah dibaca secara lengkap. Tabel frekuensi merupakan cara penyajian yang paling umum untuk deskripsi data dan digunakan untuk peubah katagorik. Tabel ini menampilkan katagori-katagori yang muncul dalam gugus data beserta frekuensi masingmasing (Saeffudin dkk, 2009).

\section{HASIL DAN PEMBAHASAN}

\section{Gambaran Responden di Kecamatan Sukaraja}

Dari hasil penelitian yang telah dilakukan, Ada sebanyak 100 responden yang dipilih secara acak untuk mewakili responden yang ada di Kecamatan Sukaraja Kabupaten Seluma. Dengan responden yang melakukan aktifitas commuter ke Kota Bengkulu sebanyak 56 orang dan responden yang tidak melakukan aktifitas commuter sebanyak 44 orang. Serta diperoleh data mengenai responden menurut pendapatan, umur, tingkat pendidikan, status pernikahan, jenis kelamin, dan status kepemilikan sebagai berikut:

\section{Karakteristik responden berdasarkan pendapatan}

Pendapatan adalah jumlah penghasilan tiap bulan dari responden yang diukur dengan satuan rupiah. Pendapatan responden di Kecamatan Sukaraja Kabupaten Seluma adalah sebagai berikut: 
Tabel 2 Responden Berdasarkan Tingkat Pendapatan Perbulan

\begin{tabular}{lccc}
\hline Pendapatan (Rp) & Commuter & $\begin{array}{c}\text { Tidak } \\
\text { Commuter }\end{array}$ & Jumlah Responden \\
\hline $300.000-900.000$ & 3 & 20 & 23 \\
$1.000 .000-1.600 .000$ & 18 & 13 & 31 \\
$1.700 .000-2.300 .000$ & 21 & 7 & 28 \\
$2.400 .000-3.000 .000$ & 12 & 4 & 16 \\
$3.100 .000-3.700 .000$ & 1 & - & 1 \\
$3.800 .000-4.300 .000$ & 1 & - & 100 \\
\hline Jumlah & 56 & 44 & \\
\hline
\end{tabular}

Sumber : Data Primer Diolah, April 2019

Pada Tabel 2 menunjukkan bahwa jumlah responden yang melakukan commuter paling banyak yaitu pada katagori pendapatan sebesar Rp 1.700.000 - Rp 2.300.000 dengan jumlah responden sebanyak 21 orang dari 28 responden yang berprofesi sebagai Tukang, swasta dan penjaga toko. Sedangkan 7 responden yang tidak melakukan commuter berprofesi sebagai wiraswasta dan petani. Selanjutnya jumlah responden yang paling sedikit melakukan commuter jika dilihat dari proporsinya yaitu dengan katagori pendapatan sebesar Rp300.000 - Rp900.000, dengan jumlah responden sebanyak 20 orang dari 23 responden. Responden yang termasuk dalam kategori ini yaitu pekerja lepas, petani, responden yang memiliki usaha kecil dengan modal terbatas dan sebagian dari mereka juga berprofesi sebagai ibu rumah tangga yang membuka usaha di rumah. Sedangkan 3 responden yang melakukan commuter berprofesi sebagai ART dan penjaga toko. Jumlah Responden yang memiliki pendapatan terbesar yaitu Rp 3.800.000- 4.300 .000 dengan jumlah responden sebanyak 1 orang, responden tersebut berprofesi sebagai wiraswasta dan juga melakukan commuter.

Adapun daerah tempat mereka bekerja yaitu di Kota Bengkulu. Keadaan ini sesuai dengan teori migrasi Todaro (2003) bahwa migrasi berlangsung sebagai tanggapan terhadap adanya perbedaan pendapatan yang terjadi antara perkotaan dan pedesaan. Di Kecamatan Sukaraja pendapatan yang diperoleh masing-masing responden pada tiap bulan memiliki jumlah yang berbeda. Ada yang pendapatannya tinggi dan ada pula yang pendapatannya rendah. Tinggi rendahnya pendapatan tersebut sangat mempengaruhi sikap dan perilaku kehidupan keluarga yang bersangkutan.

Salah satu alasan responden adalah kondisi pendapatan keluarga yang rendah mendorong responden tersebut melakukan mobilitas non permanen (commuter) untuk mendapatkan pendapatan yang lebih tinggi. Namun ada juga responden yang berasal dari keluarga berpenghasilan tinggi masih saja melakukan commuter, hal tersebut mereka lakukan karena alasan kesesuain dengan pendidikan dan kepuasan terhadap pekerjaan di daerah tujuan. Selain alasanalasan tersebut, responden melakukan commuter dikarenakan memang sudah menyempitnya lapangan pekerjaan di daerah asal dikarenakan lahan pertanian yang semakin berkurang. Keadaan tersebut selaras dengan teori Munir dalam Adioetomo dan Samosir (2010) yang menyebutkan bahwa salah satu faktor pendorong yang menyebabkan penduduk melakukan migrasi adalah menyempitnya lapangan pekerjaan di daerah asal dan makin berkurangnya sumber-sumber alam.

\section{Karakteristik responden berdasarkan kelompok umur}

Umur merupakan suatu pembeda kekuatan fisik dari responden yang dapat mempengaruhi keinginan untuk melakukan mobilitas non permanen (commuter) umur responden yang 
melakukan mobilitas non permanen (commuter) dan tidak melakukan mobilitas non permanen (commuter) di Kecamatan Sukaraja Kabupaten Seluma adalah sebagai berikut:

Tabel 3 Responden Berdasarkan Kelompok Umur

\begin{tabular}{lccc}
\hline Umur (tahun) & Commuter & Tidak Commuter & $\begin{array}{c}\text { Jumlah } \\
\text { Responden }\end{array}$ \\
\hline 15 th -20 th & 10 & 2 & 12 \\
21 th -25 th & 14 & 4 & 18 \\
26 th -30 th & 14 & 5 & 19 \\
31 th -35 th & 6 & 3 & 9 \\
36 th -40 th & 7 & 4 & 11 \\
41 th -45 th & 3 & 16 & 19 \\
46 th -50 th & 1 & 4 & 5 \\
51 th $-55^{\text {th }}$ & 1 & 4 & 5 \\
55 th -60 th & - & 2 & 2 \\
\hline Jumlah & 56 & 44 & 100 \\
\hline
\end{tabular}

Sumber : Data Primer Diolah, April 2019

Pada Tabel 3 menunjukkan bahwa jumlah responden yang paling banyak melakukan commuter yaitu pada katagori umur antara 21 th -25 th dengan jumlah responden sebanyak 14 orang dari 18 responden dan katagori umur antara 26 th -30 th dengan jumlah responden sebanyak 18 orang dari 19 responden. Jumlah responden yang paling banyak tidak melakukan commuter yaitu pada katagori umur 41 th -45 th dengan jumlah responden sebanyak 16 orang dari 19 responden. Sebagian besar responden baik laki-laki maupun perempuan yang melakukan migrasi komutasi berada pada usia produktif yaitu usia antara 15-40 tahun sebanyak 51 responden. Semakin tua umur responden di Kecamatan Sukaraja maka cenderung lebih memilih untuk tidak melakukan commuter dan bekerja di daerah asal sebagai petani atau membuka usaha dengan modal kecil di daerah asal. Bagi mereka yang memiliki anak yang sudah dewasa cenderung mendorong anak-anak mereka untuk melakukan mobilitas non permanen commuter dari pada mereka sendiri yang melakukan migrasi tersebut.

\section{Karakteristik responden menurut lama menempuh pendidikan}

Tingkat Pendidikan dapat membe-dakan bentuk suatu aktivitas yang dapat dilakukan oleh seorang responden. Tingkat Pendidikan responden yang melakukan commuter dan lainnya yang tidak termasuk kategori commuter di Kecamatan Sukaraja Kabupaten Seluma adalah sebagai berikut:

Tabel 4 Responden berdasarkan lamanya pendidikan yang ditempuh

\begin{tabular}{lccc}
\hline $\begin{array}{l}\text { Lama Pendidikan yang } \\
\text { ditempuh (Tahun) }\end{array}$ & Commuter & $\begin{array}{c}\text { Tidak } \\
\text { Commuter }\end{array}$ & Jumlah Responden \\
\hline SD/MI & 7 & 20 & 27 \\
SMP/MTS & 18 & 12 & 30 \\
SMA/SMK & 23 & 10 & 33 \\
SARJANA & 8 & 2 & 10 \\
\hline Jumlah & 56 & 44 & 100 \\
\hline
\end{tabular}

Sumber : Data Primer Diolah, April 2019

Pada Tabel 4 menunjukkan bahwa responden didominasi oleh mereka yang telah menyelesaikan pendidikan SMA/SMK dengan jumlah 33 orang hal ini dikarenakan sebagian besar responden yang terpilih di Kecamatan Sukaraja sudah peduli akan pendidikan anak-anak mereka, akan tetapi 
mereka biasanya tidak memiliki biaya lebih untuk menyeko- lahkan lagi anak-anak mereka ke jenjang yang lebih tinggi dan membuat anak-anak mereka memilih untuk bekerja setelah lulus. Hal tersebut yang membuat responden dengan lulusan SMA/SMK di Kecamatan Sukaraja paling banyak melakukan commuter jika dibanding dengan lulusan dari tingkat pendidikan lainnya.

Kemudian responden dengan tingkat pendidikan SMP/MTS sebanyak 30 orang dengan jumlah responden yang melakukan commuter paling banyak ke dua yaitu sebanyak 18 responden. Responden di kategori ini biasanya mereka yang memang berasal dari keluarga yang kurang mampu dalam segi ekonomi. Selanjutnya responden dengan tingkat pendidikan SARJANA sebanyak 10 orang dengan jumlah responden yang melakukan commuter sebanyak 8 responden dan yang tidak melakukan commuter sebanyak 2 responden. Yang terakhir responden dengan tingkat pendidikan SD/MI sebanyak 27 orang dengan jumlah responden yang melakukan commuter paling sedikit yaitu hanya 7 responden dan sisanya 20 responden tidak memilih untuk melakukan commuter karena sebagian dari mereka adalah ibu rumah tangga dan membuka usaha di rumah serta bekerja sebagai buruh di pertanian sehingga mereka merasa bekerja di desa cukup untuk memenuhi kehidupan mereka.

\section{Kaarakteristik responden menurut status pernikahan}

Status pernikahan memungkinkan seorang responden untuk setiap saat pulang ke rumah (daerah asal). Hal ini memungkinkan karena pertimbangan responden terhadap keluarga yang tinggal di rumah (daerah asal). Jumlah responden menurut status pernikahan sebagai berikut

Tabel 5 Responden Menurut Status Pernikahan

\begin{tabular}{lccc}
\hline Status Pernikahan & Commuter & $\begin{array}{c}\text { Tidak } \\
\text { Commuter }\end{array}$ & Jumlah Responden \\
\hline Menikah & 29 & 42 & 71 \\
Tidak Menikah & 27 & 2 & 29 \\
\hline Jumlah & 56 & 44 & 100 \\
\hline Sumber : Data Primer Diolah, April 2019 & &
\end{tabular}

Pada Tabel 5 menunjukan bahwa sebagian besar responden yaitu berstatus menikah dengan jumlah responden sebanyak 71 orang dengan responden yang melakukan commuter sebanyak 29 orang. Jika dibandingkan antara jumlah responden dan responden yang melakukan commuter responden dengan status tidak menikah lebih banyak melakukan commuter yaitu sebanyak 27 orang . Responden melakukan commuter dalam status menikah memiliki motivasi untuk mendapatkan pendapatan yang lebih tinggi semakin besar demi mencukupi kebutuhan keluarga.

\section{Karakteristik responden menurut jenis kelamin}

Jenis kelamin dapat membedakan kekuatan fisik dari seseorang yang memungkinkan terciptanya keputusan melakukan mobilitas non permanen commuter Responden yang berjenis kelamin lakilaki maupun berjenis kelamin selain laki-laki mempunyai kesempatan yang sama dalam melakukan pekerjaan. Jenis kelamin responden yang melakukan mobilitas non permanen (commuter) dan lainnya yang tidak termasuk dalam kategori melakukan mobilitas non permanen (commuter) di Kecamatan Sukaraja Kabupaten Seluma adalah sebagai berikut :

Tabel 6 Responden Berdasarkan Jenis Kelamin

\begin{tabular}{cccc}
\hline Jenis Kelamin & Commuter & Tidak Commuter & Jumlah Responden \\
\hline Laki laki & 42 & 22 & 64 \\
Perempuan & 14 & 22 & 36 \\
\hline Jumlah & 56 & 44 & 100
\end{tabular}

Sumber : Data Primer Diolah, April 2019 
Pada Tabel 6 menunjukkan bahwa jumlah responden berjenis kelamin laki-laki lebih banyak yaitu 64 orang dari total responden dan responden laki-laki yang melakukan commuter sebanyak 42 orang. Hal ini terjadi karena memang sebagian besar dari mereka adalah kepala keluarga atau tulang punggung di keluarganya. Sedangkan jumlah responden berjenis kelamin perempuan lebih sedikit yaitu hanya 36 orang dan yang melakukan commuter sebanyak 14 orang karena sebagian besar perempuan di Kecamatan Sukaraja hanya murni berprofesi sebagai ibu rumah tangga dan biasanya mereka hanya memiliki usaha sampingan sebagai pemilik usaha kecil dengan modal terbatas. Jika perempuan melakukan commuter itu dengan jarak yang tidak terlalu jauh.

\section{Karakteristik responden menurut status kepemilikan lahan}

Kepemilikan lahan di daerah asal dapat menjadi pertimbangan bagi orang untuk melakukan mobilitas non permanen (commuter). Hal ini dapat didasarkan pada pertimbangan atas pengolahan tanah yang dapat dilakukan di daerah asal dan bisa menjadi sumber penghasilan bagi setiap responden. Responden menurut status kepemilikan lahan di Kecamatan Sukaraja sebagai berikut:

Tabel 7 Responden menurut status kepemilikan lahan

\begin{tabular}{lccc}
\hline $\begin{array}{l}\text { Status kepemilikan } \\
\text { lahan }\end{array}$ & Commuter & Tidak Commuter & $\begin{array}{c}\text { Jumlah } \\
\text { Responden }\end{array}$ \\
\hline $\begin{array}{l}\text { Mimiliki Lahan } \\
\begin{array}{l}\text { Tidak Memiliki } \\
\text { Lahan }\end{array}\end{array}$ & 11 & 23 & 34 \\
\hline Jumlah & 45 & 21 & 66 \\
\hline
\end{tabular}

Sumber : Data Primer Diolah, April 2019

Pada Tabel 7 menunjukkan bahwa di Kecamatan Sukaraja Kabupaten Seluma penduduk yang memiliki lahan garapan adalah sebanyak 34 orang,angka yang lebih sedikit dibandingkan dengan mereka yang tidak memiliki lahan garapan. Sedangkan 66 orang lainnya tidak memiliki lahan garapan dan responden yang berstatus tidak memiliki lahan merupakan responden yang paling banyak melakukan commuter yaitu sebanyak 45 orang. Responden yang melakukan commuter lebih banyak responden yang tidak memiliki lahan pertanian karena menyempitnya lahan pertanian membuat masyarakat berganti profesi yang sebelumnya menjadi petani sekarang menjadi pedagang, pekerja lepas, tukang dan lainya. Selain itu masyarakat yang memiliki lahan pertanian juga melakukan mobilitas non permanen (commuter) yang bertujuan untuk menambah pendapatan dari penghasilan pertanian yang tidak menentu di daerah asal hal inilah yang terjadi di Kecamatan Sukaraja Kabupaten Seluma. Selain data-data yang telah dijelaskan sebelumnya terdapat data yang menyatakan bahwa dalam melakukan mobilitas non permanen commuter setiap responden memiliki alasan tersendiri yaitu sebagai berikut:

Tabel 8 Alasan Responden Melakukan Commuter

\begin{tabular}{lc}
\hline Alasan & Commuter \\
\hline Mendapatkan upah lebih tinggi & 33 \\
Lapangan kerja yang lebih sesuai & 7 \\
Kesempatan kerja lebih banyak & 10 \\
Tuntutan Pekerjaan & 2 \\
Lainnya & 4 \\
\hline Jumlah & 56 \\
\hline
\end{tabular}

Sumber : Data Primer di olah, juni 2019 
Pada Tabel 8 menunjukan bahwa alasan terbanyak responden melakukan commuter yaitu untuk mendapatkan upah yang lebih tinggi karena setelah melakukan commuter responden mendapatkan upah yang lebih tinggi dari sebelum melakukan commuter. Selain itu responden melakukan commuter karena di Kota Bengkulu terdapat kesempatan kerja yang lebih banyak, berbeda dengan di desa yang sangat mengandalkan sektor pertanian sebagai mata pencarian. Alasan lainnya yaitu lapangan kerja yang lebih sesuai, responden yang memberikan alasan ini rata rata berpendapat bahwa di Kota Bengkulu lapangan kerja sangat bervariasi tidak seperti di desa yang tidak sesuai dengan harapan mereka ataupun keahlian mereka. Selanjutnya yaitu tuntutan pekerjaan dimana responden melakukan commuter karena pekerjaannya sebagai Pegawai Negeri Sipil (PNS) yang di tugaskan di Kota Bengkulu. Yang terakhir adalah alasan lainnya dalam melakukan commuter berdasarkan hasil wawancara alasan lainnya yang disampaikan oleh responden adalah mereka melakukan commuter karena keinginan orang tuanya untuk bekerja di kota, selain itu juga karena responden memiliki keluargadi kota dan ikut temannya yang bekerja di kota.

Selain itu juga terdapat alasan responden tidak melakukan mobilitas non permanen commuter sebagai berikut:

Tabel 9 Alasan Responden Tidak Melakukan Commuter

\begin{tabular}{lc}
\hline Alasan & Tidak Commuter \\
\hline Mempunyai lahan garapan sendiri & 23 \\
Faktor keluarga & 6 \\
Kurang pengalaman bekerja & 11 \\
Tidak mau bekerja & 4 \\
Lainnya & - \\
\hline Jumlah & 44 \\
\hline
\end{tabular}

Sumber : Data Primer di olah, juni 2019

Pada Tabel 9 menunjukan bahwa alasan terbanyak responden tidak melakukan commuter karena mempunyai lahan garapan sendiri, mereka yang mempunyai lahan garapan sendiri sangat menggantungkan hidupnya dari hasil pertanian sehingga mereka memfokuskan diri mereka untuk mengelola lahan pertanian yang mereka miliki. Selain itu responden tidak melakukan commuter karena tidak memiliki pengalaman bekerja sehingga mereka memilih bekerja di desa sebagai wiraswasta, buruh di perkebunan atau buruh di sawah. Alasan lainnnya yaitu faktor keluarga dimana responden tersebut berprofesi sebagai ibu rumah tangga yang harus mengurusi keluarganya dan juga ada ibu rumah tangga yang tidak diizinkan suaminya untuk bekerja. Terakhir yaitu alasan responden tidak ingin bekerja karena mereka memiliki anak balita, mereka ingin fokus merawat anak anak mereka karena penghasilan suami mereka dirasa cukup untuk memenuhi kebutuhan hidup.

Kemudian dalam melakukan mobilitas non permanen commuter semua responden melakukan dengan menggunakan kendaraan sepeda motor karena dengan kendaraan jenis ini mereka berpendapat bahwa harga untuk membeli bahan bakar terjangkau dan mereka yang melakukan commuter adalah masyarakat yang berada pada ekonomi menengah ke bawah sehingga kebanyakan dari responden memiliki kendaraan jenis sepeda motor. Dengan kendaraan ini responden hanya mengeluarkanb iaya untuk membeli bahan bakar minyak (BBM) sebesar Rp 10.000 - Rp 35.000 untuk sekali melakukan commuter. Banyak atau sedikitnya biaya yang dikeluarkan oleh responden sesuai dengan jarak tempat mereka bekerja. 


\section{KESIMPULAN DAN SARAN}

Berdasarkan hasil dari analisis deskriptif Karakteristik Tenaga Kerja Commuter di Kecamatan Sukaraja menunjukan bahwa setiap perbedaan dari variabel pendapatan yang diperoleh oleh setiap responden, perbedaan umur responden, lama menempuh pendidikan, status pernikahan, perbedaan jenis kelamin dan kepemilikan lahan dapat mempengaruhi keputusan tenaga kerja di Kecamatan Sukaraja melakukan mobilitas non permanen (commuter).

\section{DAFTAR PUSTAKA}

Adioetomo dan Omas. 2011. Dasar-dasar Demogarafi. Jakarta: Salemba Empat.

Asep Djadja Saefullah. 1994. Mobilitas Penduduk dan Perubahan di Pedesaan. Jurnal Prisma. 23(7):35-47.

Badan Pusat Statistik. 2018. Jumlah Penduduk di Kabupaten Seluma Menurut Masing Masing Kecamatan Data Sensus Tahun 2010 dan 2016. Bengkulu:Badan Pusat Statistik Kabupaten Seluma.

Badan Pusat Statistik. 2017. Jumlah Angkatan Kerja dan Tingkat Partipasi Angkatan Kerja (TPAK) di Provinsi Bengkulu Menurut Kabupaten/ Kota, Tahun 2017. Bengkulu:Badan Pusat Statistik Provinsi Bengkulu.

Badan Pusat Statistik. 2014. Jumlah Penduduk Menurut Jenis Kelamin, Kelompok Umur, Rasio Beban Tanggungan, Rasio Jenis Kelamin, Dan Kecamatan Kabupaten Seluma Tahun 2014. Bengkulu:Badan Pusat Statistik Provinsi Bengkulu.

Bambang. 2005. Metode Penelitian Kuantitatif :Teori dan Aplikasi. Jakarta : Grafindo.

Basuki, Tri Agus. 2016. Bahan Ajar Ekonometrika. Yogyakarta: Uniersitas Muhammadiyah Yogyakarta.

Hasyasyah dan Setiawan. 2012. Analisis Faktor -Faktor yang Mempengaruhi Keputusan Tenaga Kerja Menjadi Commuter dan Tidak Menjadi Commuter Ke Kota Semarang ( Kebupaten Kendal). Diponogoro Journal of Economics. 1(1):1-10.

Ida Bagoes Mantra. 1992. Mobilitas Penduduk Sirkuler Dari Desa ke Kota di Indonesia. Yogyakarta: Pusat Penelitian Kependudukan Universitas Gadjah Mada.

Indriani. 2010. Analisis Keputusan Tenaga Kerja Menjadi Commuter. Diponogoro Journal of Economics. 1(1):1-28.

Indah Susilowati. 1998. Faktor-Faktor yang Mempengaruhi Niat Tenaga Kerja Indonesia (TKI) Bermigrasi ke Malaysia (Studi Kasus di Kawasan Selangor, Malaysia). Majalah Penelitian. 10(40):1-20.

J.Siagian. 1995. Mobilitas Penduduk Lintas Perbatasan (Kasus Kalimantan Barat-Serawak). Jakarta: LP3ES.

Kuncoro. Mudrajad. 2006. Strategi Bagaimana Meraih Keunggulan Kompetitif. Jakarta: Penerbit Erlangga.

Khotijah. 2008. Analisis Faktor Pendorong Migrasi Faktor Pendorong Migrasi Warga Klaten Ke Jakarta. Tesis. Semarang: Universitas Diponogoro. Diakses pada, https:// ww w.google.com/ur 1?sa=t\&source=web\&rct= j\& url=https://core.ac.uk/d ownl oad/pdf/1 1717855.p df\& ved=2ahU KEwid3OqClJ XjAhXbh3 AKHc LwB4 UQFjAAegQIB RAB\&usg=AovV aw2TJ3A6TjfqHnGmPw-O5LE Y\&cshid=1562033941697

Lee, E.S. 1992. Teori Migrasi (terjemahan). Yogyakarta: Pusat Penelitian Kependudukan Universitas Gadjah Mada. 
Mantra. 2000. Demografi Umum.Yogyakarta: Pustaka Pelajar.

Muhammad Rizal. 2006. Keputusan Migrasi Sirkuler Pekerja Sektor Formal di Kota Medan. Jurnal Siasat Bisnis. 11(3): 249-258.

Nong ZHU. 2001. Impacts of Income Gap on Migration Decision in China. Eu des et Documents Ec 2001.17: 1-22.

Prijono Tjiptoherijianto. 1999. Sumber Daya Manusia, Kesempatan Kerja, dan Pembangunan Ekonomi. Jakarta: UI-Press.

Purnomo, Didit. 2004. Studi tentang Migrasi Migran Sirkuler Asal Wonogiri ke Jakarta. . Jurnal Ekonomi Pembangunan. 10(1): 84 - 102.

Rustariyuni. 2014. Faktor-Faktor Yang Mempengaruhi Minat Migran Melakukan Mobilitas Non Permanen Ke Kota Denpasar. Jurnal Ekonomi Universitas Udayana. 9(2) : 95 - 104.

R.Munir. 2000. Migrasi, Dasar-dasar Demografi.Edisi 2000.Jakarta: Lembaga Penerbit UI.

Rusli S. 1996. Pengantar Ilmu Kependudukan.Edisi Revisi. Jakarta: LP3ES.

Saeffudin, A, dkk. 2009. Statistika Dasar. Bogor: Grasindo.

Sugianto dkk. 2001. Teknik Sampling. Jakarta: PT Gramedia Pustaka Utama.

Todaro, Michael P. 1998. Pembangunan Ekonomi Di Dunia Ketiga. Jakarta: Erlangga.

Widarjono. 2018. Ekonometrik Pengantar dan Aplikasinya Disertai Panduan Eviews. Yogyakarta: UPP STIM YKPN.

Yeremias T. Keban. 1994. Studi Niat Bermigrasi di Tiga Kota : Determinan dan Intervensi Kebijaksanaan. Jurnal Prisma. 1(7):1-20.

Zhao Yaohui. 1999. Labor Migration and Earnings Differences: The Case of Rural China, Economic Development and Cultural Change.The University of Chicago Press Journals. 47(4): 767-782.

Zaina Abidin. 2013. Analisis Keputusan Tenaga Kerja Melakukan Migrasi Komutasi Di Kecamatan Wuluhan Kabupaten Jember. Skripsi. Semarang: Universitas Di ponogoro. Diakses pada.https ://www. google.co m/amp /s/d ocplayer.i n fo /amp/38106815-Analisiskeputusan-tenaga-kerja-melakuk an-migrasi-ko mut asi-di-kecamatan-wuluhan-kabupatenjember-skripsi-oleh-zainal-abidin-nim.html 